Milan Stamatović

Snežana Maksimović ${ }^{2}$

University of Belgrade,

Faculty of Business and Industrial Manegement
SCIENTIFIC REVIEW ARTICLE doi:10.5937/ekonomika1603111S

Received: July 12, 2016 Accepted: Septembar 9, 2016

Aleksandra Tornjanski ${ }^{3}$

High Torism School of Professional Studies, Belgrade

\title{
THE COMPARISON BETWEEN PUBLIC AND PRIVATE SECTOR EFFICIENCY - ARE THE BUREAUCRATIC PROCEDURES THE SOURCE OF INEFFICIENCY?
}

\begin{abstract}
The article suggests the importance of the research of the public policies dimensions which indicate in which ways, ratios and forms the public spending funds supply and usage are defined and what the position of certain subjects included in the process is, using the experience of developed countries. It underlines the complexity of public decision making and the importance of bureaucrats', that is, state officials' role comprehension in the understanding of public management logic. Also, salary costs make almost one quarter of the total state spending, and they are an inflexible and often inefficient way of meeting the needs of the economy and citizens in public services domain. The paper will analyze the state of the public sector in the Republic of Serbia, with the accent on the creation of a new strategic orientation of the public administration, where the labor costs would decline by implementing the modernization of labor, while the labor flexibility and the state effect would increase. The final segment also suggests the need of social attitudes change, that is, public debates sometimes suggest that people have unrealistic expectations and exaggerated requests towards the political system. Thus we can conclude that in the following years it will be necessary to stipulate reasonable rules and legal budgetary procedures constraints. This suggests possible new research framework in the specific context of public management in Serbia.
\end{abstract}

Key words: public goods, competitiveness, efficiency, rationalization, bureaucratic procedure

JEL classification: D73, M12, O11

\footnotetext{
${ }^{1}$ stamatovicm@sbb.rs

22. galena.mcl@gmail.com, snezana.maksimovic@skc.rs

3 aleksandra.tornjanski@gmail.com
} 


\title{
POREĐENJE EFIKASNOSTI JAVNOG I PRIVATNOG SEKTORA- DA LI SU BIROKRATSKE PROCEDURE IZVOR NEEFIKASNOSTI ?
}

\begin{abstract}
Apstrakt
U članku se upućuje na važnost istraživanja dimenzija javnih politika koje ukazuju na koji način, u kakvim odnosima i u kojim oblicima se odlučuje o obezbeđivanju i korišćenju redstava za javnu potrošnju i kakav je položaj pojedinih subjekata u tome kroz iskustva azvijenih država. Ukazuje se na složenost javnog odlučivanja $i$ da je za razumevanje logike javnog upravljanja bitno sagledavanje uloge birokrata-državnih službenika. Takođe, troškovi zarada čine skoro četvrtinu ukupnog trošenja države, a predstavljaju nefleksibilan, a često i neefikasan način da se obezbede potrebe privrede i građana u sferi javnih usluga. U radu će biti analizirano stanje u javnom sektoru Republike Srbije sa posebnim akcentom na stvaranje nove strateške orijentacije javne uprave gde bi se modernizacijom rada troškovi rada smanjili, a fleksibilnost rada i učinak države povećali. U završnom delu ukazuje se i na promene društvenih stavova, odnosno javne rasprave ponekad ukazuju na to da ljudi imaju preterane zahteve prema političkom sistemu i nerealna očekivanja, tako da možemo zaključiti da je u godinama koje slede zapravo potrebno formulisanje razumnih pravila i ograničenja za budžetske procedure na zakonskom nivou, što upućuje na moguće okvirenovih istraživanja u specifičnom kontekstu javnog upravljanja u Srbiji.
\end{abstract}

Ključne reči: javna dobra, konkurentnost, efikasnost, racionalizacija, birokratske procedure

\section{Introduction}

The public sector exists in every state and its purpose is to enable the public apparatus functioning and to render public services and goods. The public sector activities comprise the legal system establishment and maintenance, public goods production, public education, health care, public enterprises. The public sector efficient functioning is an important factor for the maintenance of macroeconomic stability, economic growth, standard of living and social welfare. The lack of public sector efficient functioning is a source of severe disruption of the total economic functioning. The public sector in Serbia is generally seen as oversized considering the needs and abilities of the economy and citizens which finance it. It does not match the level of Gross Domestic Product (GDP), and its every change, either positive or negative, has a direct impact on the state of economy (Anđelić, G, Đaković V. 2013, pp.63-76). Rationalization, salary cuts, public sector reorganization and public enterprises restructuring are important postulates for the national economy maintenance. Nevertheless, the state must not neglect social and health care, as well as the retirement system. Therefore it is necessary to cease the social policy led by hiring people in the public sector. Instead of that, the public sector should be transformed so that the number of the employed becomes optimal. What must be 
understood is that the employees in the public sector are there not to earn their salaries but to render services the citizens need - administrative, educational and medical - and that they are paid for it via taxes. Therefore it is necessary that the level of these services be as high as possible and at a low price.

It is very important to raise the issue of the public sector efficiency - the more efficient public sector is, it will spend less of the public funds, and its results will be better. Countries with inefficient public sector (especially the Republic of Serbia, as the efficiency research in post-transition countries shows that Serbian public sector is the least effective) can perform reforms using a set of different measures (introducing the competition in rendering services, giving concession for building the infrastructure or partial privatization and decreasing the public jurisdictions) which would decrease the necessary allocations for the public sector, and increase the quality of services that public institutions render to the citizens.

\section{The complexity of public management}

Everybody who follows the media comes across shocking stories about state inefficiency where a wrong policy of procurement is usually underlined. Such information comes from private sector. Apart from the data suggesting the state inefficiency, there are some specific assertions in these allegations. The comparison between the costs in public and private companies engaged in the similar activities indicates lower costs in private sector, regardless of the activity in question - housing, preservation of the environment, bus transportation or the processing of payroll (Arsić, M, 2010, pp.142-5). Despite this, it is difficult to obtain the data on the state inefficiency. In most cases, public and private sector do not produce the same goods, which makes it difficult to compare directly. When they do - as in the case of education - it is difficult to measure inputs - in education it is the quality of the students (but tests adequately show only some of the dimensions of what the students achieved, while the creativity and moral values encouraged by schools are usually left out).

French public enterprises have been seen as paragons of efficiency for a long time. For example, French Electric Company built nuclear plants in the whole country using the same project and thus considerably cut the costs in comparison with American nuclear power plants which were built using different projects (R. Musgrave, 2010, pp.28-29). One of the most illustrative comparative studies on productivity is the study on comparison between two railway companies in Canada, one being privately-owned and the other state-owned. This research showed that there was no significant difference in efficiency between them. It is clear that the competition gives them a strong stimulus to be efficient.

The public sector in Serbia has been under constant fire for fifteen years. The main argument of this attack refers to its 'inefficiency'. That is, considering the fact that the services provided by the public sector are not on the market, operating losses appear, which is then financed by budgetary subsides, meaning, with the money mainly obtained from taxes or borrowing (Dimitrijević, Cvetković, 2010, pp.123-9). Critics believe that if these services were rendered on the market, the budgetary losses and tax burden would decline, while the quality of services would increase. Is it really so? 
The logic of the public sector functioning and organizing in the Republic of Serbia has not changed significantly over time, although the society has gone through major changes. In other words, the public sector has not adapted to the changes of institutional design, social awareness and market flaws. If we analyze the period from 1920s, we can come to a conclusion that the state of affairs in the public sector, for those employed there or cooperating with it directly or indirectly, is far better in comparison with the privately-owned sector of the economy. A large number of public enterprises operated or still operates with losses, but their employees have significantly higher position than the average of the economy taken as a whole. Practice shows that public enterprises mainly operate with losses, and the same public enterprises pay high wages to their employees (Veselinović, 2014, pp. 143.).

. There are several reasons to expect that public enterprises will be systematically less efficient than the private ones. This fact is associated with incentives and limitations, both on the individual and organizational level.

\section{Organizational subsides}

Considering the fact that profit is not the impeller, public enterprises have little impulse to increase the productivity. In fact, these enterprises are usually propelled by the reasons harmful for the productivity - for example, providing positions for workers, especially in domains with the problem of unemployment. In some countries, public enterprises do not even have to care about losses, as they cannot go bankrupt, and all losses are compensated from the state income. In other words, they follow soft budget constraint (J. Stiglitz, 2009, pp.78). They also often do business surrounded by limited competition. The conclusion after a series of analyses conducted by the Ministry of Public Administration and Local Self-Government in Serbia in 2014, and based on which a new strategic orientation of the public administration in Serbia is to be created, is that there is a significant potential to decrease the labor costs and increase the labor flexibility and state effect by implementing better discipline and work organization, as well as by modernization of the public administration operation (MDULS, May 2014, pp. 6)

\section{HR limitations}

The concern that state officials can abuse their position and power at the expense of tax payers which can be forced to pay the services more than it is necessary led to the implementation of numerous constraints.

Private companies can hire whoever they want and give them whatever salary they wish, and if the company pays someone more than they deserve, it is at the owner's expense. However, if a state agency pays someone more than they deserve, it is at the expense of tax payers. Dishonest work of state officials is a particular issue (fairness is an important factor for public confidence). Therefore rules for the state services should be strict, which would ensure that the state hires and promotes the most qualified individuals, as well as pays them properly. These rules are very important, but also very rigid. A state agency has a problem laying off an incompetent employee, and this decreases incentives. 
The state cannot compete with private companies regarding employment of the most qualified people, as it requires big salaries, much bigger than people with the same qualifications can be offered in the state sector.

In the upcoming period, three types of analyses are necessary for defining public administration optimization possibilities and improving its efficiency, with minimization of side effects. Firstly, detailed functional analyses will, on one hand, determine to which extent it is possible to eliminate the duplication of functions in institutions (including the fusion of agencies and bodies with ministries), and on the other hand, establish which new jobs are necessary and to what extent.

Then, there is a need for the analyses of the organization and territorial layout of work and positions in the public administration, especially health service, education, justice and security, as well as the coordination of work between central and local level. Typically, the surplus of workers in regards to the actual need is larger in the places where economic and demographic trends are in decline, which means that this analysis requires a designed policy of regional development, too ( EU FWC project, 2015).

The third type of analysis implies the decision on the extent and methods of the introduction of private and nongovernmental sector in rendering public services, as well as on policies and measures which can contribute to direct transfer from the public to private sector (MDULS, May 2014, pp.8-14).

\section{Procurement constraints}

In order to avoid misuse in state procurement of goods and services on which billions of dollars are spent every year, the USA established procedures which prevent the damage of the state, although these procedures themselves sometimes lead to costs increase. In the case of one jet engine, these procedures increase the costs by as much as a third, according to the reports. In many regions, there is an insistence on auction. However, in order to do that, the state needs to define in detail what is being bought. For a T-shirt it can take thirty pages of a densely typed text, with all the details on the quality of yarn, model, etc. (H. Rosen, T. Gayer, 2009, pp.124-9)

However, as these specifications usually differ in many things from those that factories use for the private market, there is a need for a distinct production. A relatively small number of companies will consider coordination with all state regulations to be worth the effort, so the competition will be limited, and the bid prices will reflect high expenses of coordination with state specifications. Due to this, in the end the state can pay much more than it would for a similar product from the regular production.

The overall reform of the public procurement systems in Serbia started with adoption of the new Law on Public Procurement in December 2012. When the law came into effect, legal standards in this domain were largely coordinated with the EU legal acquis. The key principles of the EU public procurement functioning are the transparency, equal opportunity for all bidders, free competition and the prohibition of discrimination. Also, public procurement is a separate chapter in the EU accession negotiation process. It takes complete practical application of the new rules for the ambitious goals stipulated in the law to be achieved. According to the latest report of the Public Procurement Administration, the transparency of the public procurement procedures has significantly 
improved thanks to the new Public Procurement Portal. The success of the Portal is reflected in the increased number of the registered users; considerably increased number of tenders published on the daily basis, as well as in the more frequent daily visits to the Portal.

Unitary public procurements of basic office supplies for central state bodies under the Administration for Joint Services of Republic Bodies have been introduced, as well as unitary public procurements of medications for public hospitals and community health centers financed by the Republic Fund for Health Insurance.

The control of the law implementation has also been improved. New ways have been introduced to enhance the integrity and transparency of public tenders through yearly procurement plans and purchasers' internal acts which precisely regulate the whole procedure and the parties in the liability chain. As for the legal remedy, the Republic Board for Rights Protection has considerably strengthened its institutional capacities. With the application of the new jurisdictions it notably strengthened its credibility, too. The application of the new rules led to the first humble, still positive results which will have to continue in the following years. Thus the share of public procurement overt procedures, which are also the most transparent ones, has gone from $54 \%$ in the first half of the last year to $79 \%$ in the second half of the same year. The share of procedures without publishing the invitation, which are the most prone to corruption, fell from $24 \%$ in the first half of the last year to $11 \%$ in the second half of the same year.

The major challenge is ensuring constant and consistent application of all measures designed by the new law, with strong governmental and institutional support, especially the support of the State Audit Institution (DRI), the Anti-Corruption Agency and Council, as well as the Protection of Competition Board.

\section{Budgetary constraints}

Another thing which distinguishes state enterprises from the private ones is budgeting, especially when it comes to long-term investments. Airline companies took many years and millions of dollars to develop their systems for tickets reservation, but they could easily allocate funds for what they knew represented important investment in basic funds. Air traffic control system preventing planes collision is mainly under the jurisdiction of state bodies. Keeping pace in constant modernization of the technical equipment due to enormous increase of air traffic requires large investment. However, state budgets are approved once a year and considering budgetary constraints there is never enough money allocated for the quick modernization financing. State bodies do not see this issue as an enterprise estimating income on investment. With the implementation of the Law on Budgetary System, in 2002, the 'infrastructure' was set in the process of public funding reform and in accordance with the accepted international budgeting methodologies and practices. So far, the application has been characterized by establishing a unique budgetary and accounting system and consolidation of data associated with public spending, the implementation of treasury as a new institution in public funding system, as well as creating the environment for effectuation of budgetary discipline. However, the model of budgeting as a classic financial and accounting form of business events record failed to give the right insight in the financial effects of the chosen 
priorities of state management, or adequate monitoring of public authorities realized strategic activities, programs and projects. Thus the entire system became even more bureaucratic, so the legislator tried to introduce the concept of program budget from 2006 which was successful in five pilot-ministries in the Republic of Serbia. The enactment of the new Budgetary System Law in 2009 was supposed to be a significant step towards the strengthening of the role of budget as an instrument of strategic management in the public sector. However, the Budgetary System Law, based on the article 112 of the regulation referring to the program part of the budget, stipulates that the program model of budgeting shall be applied in total starting with Budgetary System Law enactment and Local Authority Budget Decision for 2015. Serbia should give up the incremental linear budgeting approach and start applying a model that will connect the planning process with the process of goals and activities determination, that is, which will aim at achieving optimal funds allocation in the process of choosing a desirable managing goal. Unlike classic budgeting approach, where place, type and domain of budgetary funds spending are clearly defined, in program budget schema there is another category - 'the holder of the costs'. These are budgetary programs and projects to which the activities and costs are allocated for the purpose of achieving a particular strategic goal in practice (The Ministry of Finance RS, Bulletin, 2013b, pp.6-37).

\section{Bureaucratic procedures}

There is a series of characteristics usually associated with bureaucratic behavior. Although they may not get bigger salaries for the increase of efficiency, bureaucrats often seem to enjoy the power and prestige which come from the fact that they work for the state. The problem that Niskenen ( J. Stiglitz, 2009, pp.84-90) pointed out - that state bureaucrats can act in their own interest and not in the interest of the citizens they were appointed to serve to - is one of the examples of general issues known as the problem of principal and agents relation. The problem between principal and agent is an old question of how one man can get another to do what the first one wants. Here we have an issue of how citizens (principals) can get the office-holders, state officials (agents) to act in their interest. The corresponding problem in the private sector is how shareholders (principals) can get their officials, managers and company workers (agents) to act in their interest. The problem between principal and agent is present in every organization, either state-owned or private. Managers always have problems getting their employees to act in accordance with their wishes, and if the manager is not the owner too, the owners have problems assuring that managers act in their best interest.

The employees control problem is especially drastic in large organizations, and the manager control problem in large corporations where there is no majority owner is perhaps equally serious as in state enterprises. When it was state-owned, the company 'British Petroleum' functioned slightly different than any other large oil company with diffuse ownership, like 'Texaco' (although in a certain way both organizations could act differently than a large oil company controlled by a family such as Getty). What is the difference between the situation where a company is owned by private shareholders and when it is owned by a single shareholder, the state? There is an opinion that public enterprises managers can act like private enterprises managers to a large extent. 
In both cases they have carte blanche to a large degree, which often enables them to follow personal at the expense of public interests (in the case of public enterprises), or shareholders' interest (in the case of private companies). These attitudes have recently been confirmed by frequent redemptions of a large number of shares of one's own company at prices much higher than the market price, from the shareholder who planned to take them over (so called 'green mail'). Such payment from the corporations' treasury and the commission fees which companies' management tried to incorporate in the statutes in order to impede taking over of corporations, preserved the prerogatives of the management but at the expense of shareholders (Nielsen, 1996, pp. 97).

In large organizations the problem between principal and agents is never completely solved. The most efficient ways of stimulation are rewards for 'good' behavior' (often financial) and punishments for 'bad' behavior (lay-off). Despite the fact that both public and private sector face problems with determining the incentives that would completely solve the problems with agents, these problems appear to be much bigger in the public sector, partly because state agencies are limited regarding the possibilities of rewarding their employees. Bureaucrats' wish to increase their budget perhaps offers an explanation for many aspects of bureaucratic behavior. Another important aspect of the incentives that bureaucrats receive can explain other forms of their behavior in the best way. Despite the fact that bureaucrats' salaries need not to be directly connected with their effectiveness, their long-term promotion at least partly depends on their success at work.

A bureaucrat can avoid the responsibilities for mistakes by following certain procedures which ensure that others check all his/her actions. Although this process of joint decision making also decreases an individual's possibilities to take credit for any success, bureaucrats seem to accept this kind of trade off. It is usually said that they exhibit aversion to risk. That is what partly forms the character of the bureaucracy everything has to go through certain channels (so called 'bureaucratic routine').

There are additional two factors that contribute to the domination of bureaucracy. Firstly, most of the expenses caused by risk avoidance are not borne by the bureaucrats. Instead, these expenses are borne by the entire society, through taxes needed for paying extra staff. Those who deal with bureaucracy are forced to pay extra expenses caused by the delay of 'paperwork', etc. In fact, some say that bureaucrats enjoy the bureaucratic process (Nielsen, 1996, pp. 97)

The domination of strict rules which stipulate that every proposition must be approved by several individuals has its good side too. It is not only the consequence of bureaucrats' urge to follow their own interests but also something that naturally comes from the connection based on the trust between bureaucrats and the funds they allocate. This means bureaucrats do not spend their own money but public funds. It is a common opinion that an individual should be more careful when spending other people's money than his own. Therefore greater precaution means observing certain rules which assures that funds are not spent according to any individual's interest. As the approval needs to be given by several individuals, usually no one of them has the authority to conclude an agreement at a price bigger than the one on the market and take bribes for it.

As an example of bureaucratic procedures the Cost-Benefit Analysis and environmental reports can be examined. These procedures have a clear purpose. On the other hand, as the data for a clear estimation are rarely available, such examinations often turn into formal reports with predictable results. Such reports are sometimes used by the 
opponents of a certain project as a foundation for the attempt of its delay. Thus the costs increase to the level where the project is no longer economically feasible. These delays are social loss.

An often argument against the public sector has to do with its cumbersomeness in regards to the number of employees there. Comparing the number of the employed in public sector and the total number of employed we can get the figure of $45 \%$. However, such comparison covers up the fact that the public sector is not too large as it is, but the total number of the employed is too small (over a half of people capable of working are unemployed). According to the Serbian data $1.95 \%$ of people out of the entire population work in the education sector, while the European average is $3.46 \%$. The percentage of people in health and social care is 2.24, whereas the European average is 4.74\% (https://libek.2014).

In the public sector analysis the key question is which size and structure of Serbian public administration expenses make this sector efficient in comparison with EU member states and neighboring countries as well. In order to take observation on fiscal behavior and economic structure of a country as norms, we have to define separately which public policies are being conducted, that is, which are the desired outcomes of defined public policies. The fact is there is no unique and optimal size of public sector as every country in a certain period should estimate the optimal size of public sector. For the approximation of the public sector size in different countries the data which are mainly used are those on the number of people employed in the domain of public administration, defense, mandatory social security, health and social care (The Ministry of Finance of the Republic of Serbia, 2013, pp. 24). According to the given indicators, the public sector in the Republic of Serbia does not depart from that in the EU states, which of course does not mean that its size is optimal, or that the number of employees in certain segments of public sector is too large, while in some sectors the number of the employees is not adequate. When we talk about large, sluggish and 'restraining Serbia' we also talk about large public sector wages costs. Expenditures of the wages, that is, salaries of the employed in public sector in the Republic of Serbia make almost a quarter of the total public expenditures, while they make around $12 \%$ in the context of GDP (Eurostat, RBS, 2014). Nevertheless, it should be considered that a large step towards the reduction of wages costs was taken last year in October (public sector wages were cut by $10 \%$ ). However, it is important to underline that these reductions in public administration should not be implemented only for the sake of saving and rationalization, but predominantly because of modernization. Because wages for full-time and part-time jobs are used as a measure of number of people on fixed positions, that is, of people who do the same job every day. The description and practice of such jobs are very difficult to change. A modern country today needs to be able to change quickly, as in today's dynamic, global surroundings jobs quickly become less important, redundant or outdated. A modern country needs to invest frequently, not only in classic infrastructure, but in informational and communication technologies, new ways of work, new skills and solutions. These are exactly the costs of public administration that represent wages for some citizens, but also provide better services to the society (MDULS, 2015, pp.13).

Still, the field of political battle is not very simple, but the public sector defense is important, among other things, because less availability of public services, that is, a smaller number of the people employed and smaller salaries, means decline of economic 
activity, as then the spending declines too, and thus fewer services of the public sector for all others (Mihajilović, Mihić, Rađenović, 2013, pp. 168-176).

A radically different approach would mean defense of the workers and their social functions in public sector, a greater participation for 'users' themselves, citizens in management and decision making in public sector. It is completely obvious that the structure of the employed in the public sector is top heavy, meaning that there is a great number of managing positions and a large gap between these positions and the workers' salaries, as well as additional income for the participations in different board and committees. The first step could be the increase of income tax rate, as it does not participate much in the budget as it is.

\section{Conclusion}

The results of many studies show that the public sector in Serbia is too large and expensive in comparison with the countries in the same region and that its results are very poor. At the same time, this means that Serbia renders very poor services to its citizens, and uses more resources than necessary for this. That is, the level of public services, according to 2014 data, could be rendered with much lower public spending of $33.7 \%$ of GDP if the efficiency of the system rose to the maximum, which makes almost one third of the current public expenditures estimated at $48.3 \%$ in 2014 (https://libek,2014). The most frequent argument against the public sector refers to its 'inefficiency' and 'wastefulness'. As the services rendered by the public sector are not at the market, there is no competition, so bureaucrats do not take care of expenditures, that is, they make losses which are then compensated from the budget (with the tax money or by borrowing). However, as all public sector services cannot be the part of the private sector, the question that arises is whether the public sector should function on the efficiency principles anyway. The market efficiency criterion measures only the financial gain and losses, and disregards social effects, social gain, etc. If we look at health services we can see that operating below the level of available health care and budgetary financing actually means that health services are also available to the citizens with earnings below the average. This would not be the case if the prices of private clinics were generally used. The same goes for communal services. It should be emphasized that private businesses and entrepreneurs are not the only ones who fill in the budget. The income tax also refers to state enterprises operating with profit. Then, public sector employees also have salary deductions and they spend their earnings on goods for which they pay VAT and excise duties. All this shows that we should think carefully when the answer to liberal pressures should be salary reduction, because the reduced spending of the public sector employees due to salary reduction also causes the decline in their financial and social welfare, with the already poor social standard in Serbia.

If the efficiency of the public sector tax increases, high budgetary deficit can decline, without the public services quality decline, or even with its rise. It is also believed that the public sector efficiency increase would make room for the decrease of high tax rates which impede the private sector development and new employment. All this suggests that there is a room for the private sector improvement. The state intervention should obstruct the market as little as possible without external, usually negative, effects, which are rarely included in the investment expenditures and often 
completely neglected. According to the transition indicators of the European Bank for Reconstruction and Development and the international competition indicators of the World Economic Forum, Serbia falls behind the successful transition countries. Serbia based its economic growth more on the domestic spending growth and import than on the reforms and competition. (Maksimović, 2012, pp.102.).

The public sector changes have their institutional, reform and social aspect. This paper shows the way we should think when it comes to the public sector operation, and that reform course means the improvement of public enterprises corporative management and the strengthening of the professionalism of public enterprises executives.

Budgetary programs should become key information carriers and the managing instrument in the exercise of public authority system. These should help the integration of different elements which should form a unique managing system that will provide:

- clear definition and exhibition of the public authority goals

- identification of the alternative ways of achieving goals in practice by different activities of budget users

- determination of the costs and benefits for every alternative solution separately;

- $\quad$ selection of alternatives according to the maximum net worth and net social benefit of the budgetary program

The introduction of program budget is a demanding task for the public sector organizational systems in the Republic of Serbia. Besides, the advantages of this budgeting model are not immediately visible in practice. For this model to be adequately implemented it takes a significant reform in the operation of the managing structure units of the public authorities and permanent work on the state officials and executives training. What is also necessary is the improvement of strategic and operative methodology, analytical capacities development and precise definition of jurisdiction and responsibilities for the budgetary program implementation. In fact, the process of budget planning and making should be coordinated with the public sector management methodology, and this takes many years of careful, systematic and professional work.

Of course, numerous open questions regarding the ways of operating improvement as well as the model and form of the public sector financing, still remain connected to this topic trying to find the best way to obtain certain managing goals and the results of public operation, but also the awareness of the price and the final effects of certain projects in practice.

\section{References}

Anđelić, G., Đaković V.(2013) Reforma javnog sektora Republike Srbije- pravci, trendovi i izazovi, str.63-76.

Arsić,M. I drugi (2010)Reforma javnog sektora, Ekonomski fakultet,Beograd, str.142-5.

Clark, R. L.,Sandler Morrill, M\& Vanderweide, D.(2014) Defined benefit pension plan distribution decisions by public sector employees, Journal of Public Economics, 116 (1) 7-'88 
Dimitrijević, M., Cvetković,Z. (2010) Reforma javnog sektora u Republici Srbiji po modelu javno-privatnog partnerstva. Anali međunarodne konferencije maldih lidera ,123-9.

Đekić Ivan (2015) Unapređenje ljudskog kapitala u Srbiji, Ekonomika, NIš, str.133148

Ivanišević Milorad, POSLOVNE FINANSIJE, (2008)Ekonomski fakultet, Beograd,str.234.

.https://libek.org.rs/sr/istrazivanja/2014/10/09/racionalizacija-broja-zaposlenihjavnom-sektoru

Maksimović, Lj. (2012) Sistemska oraničenja konkurentnosti privrede Srbije. Ekonomski horizonti, 14(2),99-109

Mihajilović,M.,Mihić, S., Rađenović, D. (2013) Restrukturiranje javnih preduzeća u Srbiji- usmeravanje ka tržišnim principima poslovanja, Poslovna ekonomija, $7(1), 157-176$.

Musgrave R., Teorija javnih finansija, (2010) Naučna knjiga, Beograd, 28-29.

Ministarstvo državne uprave i lokalne samouprave (2015) Moderna državaracionlan država:koliko, kao i zašto?,Beograd, 6-27.

Ministarstvo finansija Republike Srbije (2011)Analiza poslovanja u javnim preduzećima u 2010 godini, Beograd

Ministarstvo finansija Republike Srbije (2013a). Informacija o paketu mera za stabilizaciju javnih finansija i oporavak privrede, Beograd

Ministarstvo finansija Republike Srbije (2013b)Bilten javnih finansija, Beograd, 17 decembar,str. 6-37

Nielsen, R.P. „Piggybacking Strategies for Nonprofits: A shared Costs Approach, "Strategic Management Journal, 97, (1996).

Raičević Božidar, (2008) JAVNE FINANSIJE, Beograd, Srbija, Ekonomski fakultet Univerziteta u Beogradu

Republički zavod za statistiku (2013). Anketa o radnoj snazi. http://webrzs.stat.gov. rs/WebSite/

Rosen, S. HarveyTed Gayer, (2009)JAVNE FINANSIJE, Univerzitet Prinston, osmo izdanje, 124-9.

Stiglitz, E. Joseph, (2008)EKONOMIJA JAVNOG SEKTORA, drugo izdanje, Beograd,78-93.

Program povećanja energetske efikasnosti, JSP Šabac, maj 2014. god.

Regionalna privredna komora Valjevo, Finansijski rezultati poslovanja, Mart, 2015. God

Veselinović, P (2014), Reforma javnog sektora kao ključna determinanta uspešnosti tranzicije privrede Republike srbije, Ekonomski horizonti, 16(2), 141-159

Vuković,V.(2014), Javni sektor u Srbiji: između mita i stvarnosti, bilten.org

Zakon o javnim preduzećima, Službeni glasnik Republike Srbije, br.119/2012, br.116/2013, br.44/2014-dr.zakon. 